\title{
KEEFEKTIFAN MODEL PEMBELAJARAN KOOPERATIF TIPE CONCEPT SENTENCE DALAM KETERAMPILAN MENULIS KARANGAN DESKRIPSI BAHASA JERMAN SISWA KELAS XI IPA SMA NEGERI 12 MAKASSAR
}

\author{
Ikawati Awing ${ }^{1}$ dan Nurming Saleh ${ }^{2}$ \\ Bahasa dan Sastra, Universitas Negeri Makassar \\ E-mail1': ikawatiawing765@gmail.com
}

\begin{abstract}
ABSTRAK
Tujuan Penelitian ini adalah untuk memperoleh data dan informasi mengenai keterampilan menulis karangan deskripsi bahasa Jerman siswa kelas XI IPA SMA Negeri 12 Makassar dengan model pembelajaran kooperatif tipe concept sentence. Penelitian ini merupakan quasi experiment dengan bentuk control group pretest and posttest design. Populasi penelitian ini adalah siswa kelas XI IPA SMA Negeri 12 Makassar yang terdiri dari 7 kelas. Jumlah sampel adalah 24 siswa kelas XI IPA 1 sebagai kelas eksperimen dan 24 siswa kelas XI IPA 2 sebagai kelas kontrol melalui sample acak. Data penelitian ini diperoleh melalui teks keterampilan menulis dan dianalisis dengan uji-t.Hasil analisis data $\mathrm{t}_{\text {hitung }} 2,45>\mathrm{t}_{\text {tabel }} 2,013$ dengan taraf signifikan $\alpha=0,05$ dan menunjukkan bahwa model pembelajaran kooperatif tipe concept sentence efektif dalam pembelajaran keterampilan menulis karangan deskripsi bahasa Jerman siswa kelas XI IPA SMA Negeri 12 Makassar.
\end{abstract}

\section{Kata Kunci: Model Kooperatif, Tipe Concept Sentence, Keterampilan Menulis}

\begin{abstract}
The purpose of this study was to collect data and information about description essay writing skill in German language class XI IPA SMAN 12 Makassar by using cooperative learning model especially type pf concept sentence. This study was a quasi experiment by using pretest and posttest control group design. The study population was the students of class XI IPA SMAN 12 Makassar which consisted of 7 classes. The number of samples was 24 students took from class XI IPA 1 as an experimental class and 24 students from class XI IPA 2 as the control class through a random sample.The research data was obtained through the text writing skill and analyzed by t-test. The results of the data analysis showed $2,45 \mathrm{t}$ count> $\mathrm{t}$ table 2.013 with significance level $\alpha=0.05$ and showed that the model was effective to apply in the german essay writing skill learning class XI IPA SMAN 12 Makassar.
\end{abstract}

\section{Keywords: Cooperative Model, Type of Concept Sentence, Writing Skill}

\section{PENDAHULUAN}

Mengingat pentingnya bahasa, maka pelajaran bahasa di sekolahsekolah sudah diterapkan mulai dari Sekolah Dasar (SD) hingga Sekolah Menengah Atas (SMA) tidak hanya bahasa nasional melainkan juga bahasa asing. Salah satu bahasa Asing yang diajarkan di sekolah adalah bahasa Jerman.

Pada pembelajaran bahasa Jerman, ada empat kompetensi yang 
harus dikuasai. Kompetensi tersebut adalah menyimak (Hörverstehen), berbicara (Sprechfertigkeit), membaca (Leseverstehen) dan menulis (Schreibfertigkeit), serta ada dua aspek penunjang yang meliputi kemampuan tata bahasa dan kosakata (Strukturen und Wortschatz) yang masing-masing keterampilan berbahasa tersebut saling berhubungan satu dengan yang lainnya.

Berdasarkan hasil observasi awal di SMA Negeri 12 Makassar menunjukkan bahwa tingkat keterampilan menulis bahasa Jerman siswa masih kurang khususnya dalam keterampilan menulis karangan deskripsi. Hal ini disebabkan karena masih banyak siswa mengalami kesulitan dalam menulis sebuah karangan deskripsi dan metode yang digunakan oleh guru bahasa Jerman di sekolah tersebut tidak bervariasi, sehingga penyampaian materi pelajaran menjadi kurang menarik dan menyebabkan siswa bosan mengikuti pelajaran bahasa Jerman.

Hal ini didukung dari penelitian sebelumnya yang dilakukan oleh Musdalifah (2014:55) menunjukkan bahwa kemampuan menulis karangan deskriptifbahasa Jerman siswa kelas XI IPS SMA Negeri 1 Tombolo Pao tergolong rendahdengan nilai $40,61 \%$. Hasil penelitian yang dilakukan oleh Suhardi (2008:50) menyatakan bahwa keterampilan menulis kalimat bahasa Jerman siswa SMA 1 Anggeraja Kabupaten Enrekang tergolong rendah dengan nilai 49,2 \% dan sejalan dengan penelitian yang dilakukan oleh Ramadhani (2010:48) menyatakan bahwa keterampilan menulis bahasa Jerman siswa kelas XI SMA 5 Makassar masih rendah yaitu $48,25 \%$.

Beranjak dari hal tersebut, maka siswa dituntut mampu menulis baik dalam menulis kalimat maupun menulis karangan deskripsi. Oleh karena itu, perlu adanya suatu metode pembelajaran yang dapat meningkatkan hasil belajar siswa khususnya dalam keterampilan menulis karangan deskriptif bahasa Jerman.

Salah satu metode pembelajaran yang perlu diterapkan dalam mengatasi kesulitan siswa dalam menulis karangan deskripsi bahasa Jerman adalah tipe concept sentence. Tipe concept sentence merupakan salah satu metode dimana siswa aktif dalam kelompok-kelompok kecil dengan sistem tugas yang menggunakan kata kunci.

\section{PEMBELAJARAN KOOPERATIF}

\section{Suprijono}

berpendapat bahwa pembelajaran kooperatif adalah konsep yang lebih luas meliputi semua jenis kerja kelompok termasuk bentuk-bentuk yang lebih dipimpin oleh guru atau diarahkan oleh guru. Pendapat lain dikemukakan oleh Hammoud dan Ratzki (2009:6) bahwa pembelajaran kooperatif adalah bentuk pembelajaran terstruktur yang mempunyai fungsi yang sama yaitu untuk membahas isi pembelajaran secara ilmiah, seperti latihan perilaku sosial kooperatif. 
Hal ini senada dengan yang dikemukakan oleh Artz dan Newman dalam Huda (2013:32) bahwa pembelajaran kooperatif adalah kelompok kecil pembelajar atau siswa yang bekerja sama dalam satu tim untuk mengatasi suatu masalah, menyelesaikan sebuah tugas atau mencapai satu tujuan bersama.

Dari pendapat para ahli di atas, dapat disimpulkan bahwa pembelajaran kooperatif adalah suatu kegiatan belajar siswa yang dilaksanakan dengan melibatkan partisipasi siswa dalam sebuah kelompok kecil dengan arahan guru.

\section{TIPE CONCEPT SENTENCE}

Model pembelajaran Tipe concept sentence merupakan salah satu tipe model pembelajaran yang dikembangkan dari cooperative learning yang bentuk pelaksanaan pembelajarannya berupa konsep dengan menggunakan kata kunci. Sejalan dengan hal tersebut, Suprijono (2014:9) berpendapat bahwa konsep merupakan kata kunci. Tetapi tidak semua kata bisa disebut kata kunci jika kata itu tidak bersifat umum dan abstrak.

Senada dengan pendapat di atas, Arends (2008:322) mengemukakan model concept sentence telah dikembangkan untuk mengajarkan konsep-konsep kunci yang berfungsi untuk siswa berpikir dengan tingkat yang lebih tinggi dan menjadi dasar bagi pemahaman bersama dan komunikasi.

Pendapat senada dikemukakan juga oleh Guruclub (dalam Shoimin
2014:37-38) bahwa model pembelajaran tipe concept sentence merupakan model pembelajaran yang diawali dengan menyampaikan kompetensi, sajian materi, membentuk kelompok heterogen, guru menyiapkan kata kunci sesuai materi bahan ajar, dan tiap kelompok membuat kalimat berdasarkan kata kunci.

Berdasarkan pendapat para ahli di atas, maka dapat disimpulkan bahwa tipe concept sentence merupakan model pembelajaran yang menggunakan kata kunci yang kemudian kata kunci digunakan didalam membuat kalimat, dan selanjutnya kalimat tersebut dikembangkan menjadi karangan.

\section{KETERAMPILAN MENULIS}

Tarigan

(2008:3)

mengemukakan bahwa keterampilan menulis adalah salah satu keterampilan berbahasa yang produktif dan ekspresif yang dipergunakan untuk berkomunikasi secara tidak langsung dan tidak secara tatap muka dengan pihak lain. Selanjutnya Jufri (2001:88) mengemukakan bahwa keterampilan menulis sebagai suatu keterampilan dalam berbahasa (bahasa tulisan) tidaklah semudah dengan keterampilan yang lain (menyimak, berbicara, dan membaca). Keterampilan menulis membutuhkan keterampilan khusus, karena dalam menulis pembelajar bahasa harus menggunakan kata-kata yang tepat, kalimat yang baik serta mampu 
menghubungkan paragraf yang satu dengan paragraf yang lainnya.

Hal ini sejalan dengan yang dikatakan oleh Byrne dalam Jufri (2001:88) bahwa menulis jelas jauh lebih banyak daripada produksi symbol grafik, seperti pidato lebih dari produksi suara. Symbol telah diatur untuk membentuk kalimat sebagai aturan, namun kami tidak menulis hanya satu kalimat atau sejumlah kalimat yang tidak terkait diatur dalam urutan tertentu dan dihubungkan bersama dengan caracara tertentu.

Berdasarkan pendapat para ahli di atas, dapat disimpulkan bahwa keterampilan menulis adalah kemampuan mengungkapkan pendapat dengan menggunakan kosakata, gramatik dan ejaan untuk berkomunikasi dengan pihak lain secara tidak langsung.

\section{METODEPENELITIAN}

Penelitian ini menggunakan dua variabel yaitu variabel bebas dan variabel terikat. Variabel bebas ialah model pembelajaran kooperatif tipe concept sentence, sedangkan variabel terikat ialah keterampilan menulis karangan deskripsi bahasa Jerman siswa kelas XIIPA SMA Negeri 12 Makassar.

Penelitian ini merupakan penelitian kuantitatif dengan menggunakan quasi eksperimen (eksperimen semu). Desain penelitian yang digunakan dalam penelitian ini Arikunto (2009:210) control group pretest and posttest design.
Populasi dalam penelitian ini adalah seluruh siswa kelas XI IPA SMA Negeri 12 Makassar yang terdiri dari 7 kelas dengan jumlah 256siswa. Sampel yang digunakan dalam penelitian ini adalah kelas XI IPA 1 yang berjumlah 24 siswa sebagai kelas eksperimen dan kelas XI IPA 2 yang berjumlah 24 siswa sebagai kelas kontrol. Jadi, total sampelnya adalah 48 siswa. Pengambilan sampel ini ditentukan dengan cara random sampling.

Teknik pengumpulan data dalam penelitian ini menggunakan tes. Tes yang dilakukan adalah pretest dan post-test. Analisis data dalam penelitian ini akan menggunakan analisis statistik inferensial. Sebelum menguji hipotesis, terlebih dahulu menghitung rata-rata, varians dan simpangan baku, setelah itu data tersebut diuji normalitasnya dan homogenitas, kemudian menguji hipotesis dengan menggunakan uji-t.

\section{PEMBAHASAN}

Hasil yang diperoleh dari analisis data penelitian tentang keefektifan model pembelajaran kooperatif tipe concept sentence dalam keterampilan menulis karangan deskripsi bahasa Jerman siswa kelas XI IPA SMA Negeri 12 Makassar akan dipaparkan pada bagian ini.

Berdasarkan perolehan skor yang telah dipaparkan sebelumnya memberikan gambaran bahwa skor yang diperoleh siswa diajar menggunakan model pembelajaran kooperatif tipe concept sentence dalam keterampilan menulis karangan

29 Eralingua : Jurnal Pendidikan Bahasa Asing dan Sastra Volume 1 No.1 Maret 2017 
deskripsi lebih tinggi dibandingkan dengan siswa yang tidak diajar dengan menggunakan model pembelajaran kooperatif tipe concept sentence.

Penelitian ini dilaksanakan selama rentang waktu kurang lebih satu bulan dengan 4 kali pertemuan setelah pemberian pre-test di masingmasing kelas. Kelas XI IPA 1 sebagai kelas eksperimen diajar dengan menggunakan model pembelajaran kooperatif tipe concept sentence dalam keterampilan menulis karangan deskripsi sedangkan kelas XI IPA 2 sebagai kelas kontrol tetap diajar dengan menggunakan kelas metode konvensional yaitu metode ceramah.

Sesuai dengan hasil pre-test siswa di kelas XI IPA 1 sebagai kelas eksperimen menunjukkan bahwa nilai rata-rata (mean) keterampilan menulis karangan deskripsi siswa adalah 42,5 dan masih dikategori kurang yang nilai tertingginya ialah 75 dan nilai terendahnya ialah 46. Berdasarkan data distribusi frekuensi dan persentase, nilai yang paling banyak diperoleh oleh siswa ialah antara 25 32 sebanyak 10 siswa atau $41,7 \%$.

Hasil pre-test siswa di kelas XI IPA 2 sebagai kelas kontrol menunjukkan nilai rata-rata (mean) keterampilan menulis karangan deskripsi siswa adalah 33,16 dan nilainya dikategori kurang yang nilai tertinggi adalah 75 dan nilai terendah adalah 25. Berdasarkan data distribusi frekuensi dan persentase, nilai yang paling banyak diperoleh oleh siswa adalah nilai antara 25-32 sebanyak 16 siswa atau $66,67 \%$.
Berdasarkan hasil pre-test siswa kelas eksperimen dan kelas kontrol menunjukkan bahwa nilai-nilai ratarata siswa masih di bawah nilai Kriteria Kelulusan Minimal (KKM) di sekolah 70. Hal ini disebabkan oleh kurangnya motivasi dan minat siswa dalam berbahasa Jerman dan kurangnya penguasaan kosakata dalam merangkai kalimat, sehingga ketika menulis kalimat terkadang menggunakan kosakata bahasa Inggris, seperti kata My name is yang seharusnya Mein Name ist. Siswa menggunakan kata "My name is", karena siswa sudah terbiasa dengan kata tersebut dan belum tahu apa sebutannya dalam bahasa Jerman.

Setelah dilakukan pembelajaran dengan model pembelajaran kooperatif tipe concept sentence pada kelas eksperimen dan pembelajaran konvensional pada kelas kontrol, diberikan tes akhir (post-test) untuk kedua kelas. Tes akhir (post-test) ini dilakukan untuk melihat apakah model pembelajaran kooperatif tipe concept sentence efektif dibandingkan dengan pembelajaran konvensional dalam keterampilan menulis karangan deskripsi bahasa Jerman.

Berdasarkan hasil post-test siswa di kelas XI IPA 1 sebagai kelas eksperimen menunjukkan bahwa nilai rata-rata (mean) keterampilan menulis karangan deskripsi siswa adalah 50,16 dan dikategori cukup yang nilai tertingginya ialah 75 dan nilai terendahnya ialah 56. Berdasarkan data distribusi frekuensi dan persentase, nilai yang paling banyak 
diperoleh oleh siswa ialah nilai antara 49-56 sebanyak 14 siswa atau 12,5\%.

Sesuai dengan hasil post-test siswa kelas eksperimen yang menunjukkan bahwa nilai rata-rata siswa telah memenuhi nilai KKM. Hal ini dapat membuktikan bahwa model pembelajaran kooperatif tipe concept sentence dapat meningkatkan keterampilan menulis karangan deskripsi dan motivasi siswa dalam belajar bahasa Jerman.

Berdasarkan hasil post-test siswa kelas XI IPA 2 sebagai kelas kontrol menunjukkan bahwa nilai rata-rata (mean) keterampilan menulis karangan deskripsi siswa adalah 41,66 dan nilainya dikategori kurang yang nilai tertinggi adalah 75 dan nilai terendah adalah 25 . Berdasarkan data distribusi frekuensi dan persentase, nilai yang paling banyak diperoleh siswa adalah nilai antara 25-32 sebanyak 10 siswa atau 41,7\%.

Dari hasil post-test kelas kontrol di atas menunjukkan bahwa nilai rata-rata siswa masih dibawah nilai KKM. Hal ini disebabkan oleh metode pembelajaran yang digunakan oleh guru tidak bervariasi (monoton). Selain itu, metode pembelajaran yang dilakukan di kelas masih berpusat pada guru, hal ini terlihat pada saat peneliti melakukan observasi yaitu guru menjelaskan materi dalam buku, kemudian memberikan tugas yang ada pada buku kepada siswa.

Sebelum dilakukan pengujian hipotesis, terlebih dahulu dilakukan pengujian normalitas data. Dalam pengujian normalitas, data yang diambil ialah data nilai pre-test siswa kelas eksperimen dan kelas kontrol. Pengujian ini dilakukan untuk melihat apakah data yang diperoleh normal atau tidak.

Hasil uji normalitas data pretest kelas eksperimen menunjukkan bahwa data kelas eksperimen memiliku Chi Square hitung yang lebih kecil dari Chi Square tabel, $\chi_{\text {hitung }}<\chi_{\text {tabel }}(2,68<11,07)$. Hasil tersebut menunjukkan bahwa data kelas eksperimen dinyatakan normal.

Hasil uji normalitas data pretest kelas kontrol menunjukkan bahwa data kelas kontrol memiliki Chi Square hitung yang lebih kecil dari Chi Square tabel, $\chi_{\text {hitung }}<\chi_{\text {tabel }}(-12,71<11,07)$, sehingga data tersebut dinyatakan normal.

Hasil pre-test siswa di kelas eksperimen dan kelas kontrol harus diketahui pula homogenitasnya. Tujuannya ialah untuk mengetahui apakah varians kedua data tersebut homogan atau tidak. Pada kelas eksperimen menunjukkan varians yaitu 279,65, sedangkan varians kelas kontrol yaitu 166,49 . Sesuai dengan kriteria pengujiannya, hasilnya ialah $F_{\text {hitung }}<F_{\text {tabel }}(1,06<5,05)$, sehingga kedua data sampel tersebut dinyatakan memiliki varians yang sama atau homogen.

Setelah hasil analisis di atas, dilanjutkan dengan uji-t untuk melihat hasil akhir penelitian ini. Hasilnya adalah $t_{\text {hitung }} 2,45>t_{\text {tabel }} 2,013$. Sesuai dengan kriteria pengujian hipotesis yaitu tolak $\mathrm{H}_{0}$ jika $\mathrm{t}_{\text {hitung }}>\mathrm{t}_{\text {tabel}}$, maka $\mathrm{H}_{0}$ yang dalam penelitian ini adalah 
penggunaan model pembelajaran kooperatif tipe concept sentence tidak efektif dalam keterampilan menulis karangan deskripsi bahasa Jerman dinyatakan ditolak. Jika $\mathrm{H}_{0}$ ditolak, maka $\mathrm{H}_{1}$ diterima, yaitu penggunaan model pembelajaran kooperatif tipe concept sentence efektif dalam keterampilan menulis karangan deskripsi bahasa Jerman.

Sesuai dengan hasil pengujian hipotesis di atas, sehingga dapat disimpulkan bahwa $\mathrm{H}_{1}$ diterima, penelitian tentang keefektifan model pembelajaran kooperatif tipe concept sentence dalam keterampilan menulis karangan deskripsi bahasa Jerman siswa kelas XI IPA SMA Negeri 12 Makassar dinyatakan berhasil.

Hasil temuan penelitian ini menyatakan bahwa model pembelajaran kooperatif tipe concept sentence efektif dalam keterampilan menulis karangan deskripsi bahasa Jerman siswa kelas XI IPA SMA Negeri 12 Makassar sejalan dengan teori yang dikemukakan oleh Shoimin (2014:37) model concept sentence adalah model pembelajaran yang dilakukan dengan memberikan kartukartu yang berisi beberapa kata kunci kepada siswa. Kemudian, kata kunci tersebut disusun menjadi beberapa kalimat dan dikembangkan menjadi paragraf-paragraf. Model ini dilakukan dengan siswa dibentuk kelompok heterogen dan membuat kalimat dengan minimal 4 kata kunci.

\section{KESIMPULAN}

Berdasarkan uraian di atas, maka dapat disimpulkan bahwa model pembelajaran kooperatif tipe concept sentence efektif dalam keterampilan menulis karangan deskripsi bahasa Jerman siswa kelas XI IPA SMA Negeri 12 Makassar. Hal tersebut dapat dibuktikan dengan hasil analisis data yang telah dilakukan, dengan nilai post-test sebanyak 48 siswa setelah dilakukan uji-t pada masing-masing kelas dengan hasil analisis data yaitu $\mathrm{t}_{\mathrm{h}}=2,45>\mathrm{t}_{\mathrm{t}}=2,013$ pada taraf signifikansi 0,05. Berdasarkan hasil analisis data tersebut, maka $\mathrm{H}_{1}$ dinyatakan diterima dan $\mathrm{H}_{\mathrm{o}}$ dinyatakan ditolak. Oleh karena $\mathrm{H}_{1}$ diterima, maka penelitian ini dinyatakan berhasil.

\section{DAFTAR PUSTAKA}

Abidin, Yunus. 2012. Pembelajaran Bahasa Berbasis Pendidikan Karakter. Bandung: PT. Refika Aditama.

Akhadiah, Sabarti. 2003. Pembinaan Kemampuan Menulis Bahasa Indonesia. Jakarta: Erlangga.

Al-Tabany, Trianto Ibnu Badar.2014. Mendesain Model

Pembelajaran Inovatif, Progresif, dan Kontekstual. Jakarta: Prenadamedia Group.

Arends, Richard. 2008. Learning to Teach. Americas New York: McGraw-Hill Companies.

Arifin, Zainal. 2014. Penelitian Pendidikan Metode dan Paradigma Baru. Bandung: Remaja Rosdakarya.

Arikunto. 2009. Prosedur Penelitian Suatu Pendekatan Praktik. Jakarta: Rineka Cipta. 
Astrum, Megawati. 2009. Model dan Metode Pembelajaran Kreatif dan Berkarakter. Bandung: PT. Refika Aditama.

Darwis. 2014. Terampil Berbahasa. Bandung: Alfabeta.

Deporter, Bobby dan Hernacki, Mike. 2010. Quantum Learning. Bandung: PT. Mizan Pustaka.

Djiwandono, Soenardi. 2008. Tes Bahasa Pegangan bagi Pengajar Bahasa. Jakarta: Indeks.

Gie, T. L. 2002. Terampil Mengarang. Yogyakarta: Andi.

Hamdayama, Jumanta. 2014. Model dan Metode Pembelajaran Kreatif dan Berkarakter. Bogor: Ghalia Indonesia.

Hammoud, Antje dan Ratzki, Anne. 2009. Fremdsprache Deutsch Kooperatives Lernen. München: Max Heuber Verlag.

Harmer, Jeremy. 2004. How to Teach Writing. New York: longman.

Huda, Miftahul. 2013. Cooperative Learning. Yogyakarta: Pustaka Pelajar.

2014. Model-Model Pengajaran dan Pembelajaran. Yogyakarta: Pustaka Pelajar.

Jauhari, Heri. 2013. Terampil Mengarang. Bandung: Nuansa Cendekia.

Jufri. 2001. Prinsip-Prinsip Strategi Pembelajaran Bahasa. Makassar: State University of Makassar.

Junus, Muhammad. 2011. Keterampilan Berbahasa Tulis. Makassar: Badan Penerbit Umum.
Komaidi, Didik. 2011. Panduan Lengkap Menulis Kreatif. Yogyakarta: Sabda Media.

Komalasari. 2010. Pembelajaran Kontekstual Konsep dan Aplikasi. Bandung: Rafika Aditama.

Komara, Endang. 2014. Belajar dan Pembelajaran Interaktif. Bandung: PT. Refika Aditama.

Mulyasa, E. 2002. Kurikulum Berbasis Kompetensi Konsep Karakteristik dan Implementasi. Bandung: Remaja Rosdakarya.

Munira. 2003. Menulis I. Makassar. UNISMUH.

Nurgiyantoro, Burhan. 2010. Penilaian Pembelajaran Bahasa Berbasis Kompetensi. Yogyakarta: BPFE-Yogyakarta.

Nurjamal, Daeng. 2010. Penuntun Perkuliahan Bahasa Indonesia. Bandung: Alfabeta.

Nurudin. 2007. Dasar-dasar Penulisan. Malang: Umm Press.

Purwanto, M. Ngalim. 2012. PrinsipPrinsip dan Teknik Evaluasi Pengajaran. Bandung: PT. Remaja Rosdakarya.

Sanjaya, Wina. 2008. Strategi Pembelajaran Berorientasi Standar Proses Pendidikan. Jakarta: Kencana.

Semi, M, Atar. 2007. Dasar-Dasar Keterampilan Menulis. Bandung: Angkasa.

Shoimin, Aris. 2014. 68 Model Pembelajaran Inovatif dalam Kurikulum 2013. Yogyakarta: Ar-Ruzz Media.

Steets, Angelika dan Ehlich, Kohard. 2003. Wissenschaftlich 
Schreiben. Lehren und Lernen. Berlin: Water Groyter.

Sudjana. 2005. Metode Statistika. Bandung: Tarsito.

Sugiyono. 2011. Statistika Untuk Penelitian. Bandung: Alfabeta.

Suhadi. 2007. Memenangkan Lomba Mengarang. Jakarta: Balai Pustaka.

Sulistiyowati, A. 2007. Efektivitas Penggunaan Media Film "Hallo Berlin" Terhadapa Kemampuan Menulis Siswa Kelas XI Bahasa di SMA Negeri 7 Malang. Skripsi. FBS Malang.

Supardi. 2013. Aplikasi Statistika Dalam Penelitian. Jakarta: Smart.

Suprijono, Agus. 2014. Cooperative Learning Teori \& Aplikasi Paikem. Yogyakarta: Pustaka Pelajar.
2009. Sistem Pengendalian Menejemen Edisi Pertama. Yogyakarta. BPFE.

Tarigan, Henry Guntur. 2008. Menulis Sebagai Suatu Keterampilan Berbahasa. Bandung: Angkasa.

Thoifah. 2015. Statistika Pendidikan dan Metode Penelitian Kuantitatif. Malang: Madani Media.

Yamit, Zulian. 2013. Manajemen Kualitas Produk dan Jasa Edisi Kedua. Yogyakarta: Ekonisia.

Zainurrahman. 2011. Menulis: Dari Teori Hingga Praktik (Penawar Racun Plagiarisme). Bandung: Alfabeta. 